\title{
Brazilian Medicinal Plant Acts on Prostaglandin Level and Helicobacter pylori
}

\author{
Z.P. Lima, ${ }^{1}$ T.R. Calvo, ${ }^{2}$ E.F. Silva, ${ }^{3}$ C.H. Pellizzon, ${ }^{4}$ W. Vilegas, ${ }^{2}$ A.R.M.S. Brito, ${ }^{3}$ \\ T.M. Bauab, ${ }^{5}$ and C.A. Hiruma-Lima ${ }^{1}$ \\ ${ }^{1}$ Departamentos de Fisiologia and ${ }^{4}$ Morfologia, Instituto de Biociências, São Paulo State University, \\ Botucatu; ${ }^{2}$ Departamento de Química Orgânica, Instituto de Química, and \\ ${ }^{5}$ Departamento de Ciências Biológicas, São Paulo State University, Araraquara; and \\ ${ }^{3}$ Departamento de Fisiologia e Biofísica, Instituto de Biologia, \\ Campinas State University, Campinas, São Paulo, Brazil
}

\begin{abstract}
Among the current treatment strategies for the peptic ulcer patient with Helicobacter pylori infection, the method of choice is triple therapy based on the concurrent use of proton inhibitors and two antibiotics. Alchornea triplinervia is a medicinal plant commonly used by people living in the Cerrado region of Brazil to treat gastrointestinal ulcers. In the present work we proposed therapy based on this medicinal plant that presents effective gastroprotective action with antibiotic effects. Oral pretreatment with methanolic extract (ME) of A. triplinervia in rats and mice decreased the gastric injuries induced by ethanol and $\mathrm{HCl} /$ ethanol. Increasing the dose reduced the gastroprotective effects of $\mathrm{ME}$ on the gastric lesions induced by nonsteroidal anti-inflammatory drug. After pylorus ligature of mice, oral administration of ME induced a decrease not only in total acid but also in the ulcer index. We also observed that ME displayed antibacterial activity against $H$. pylori. Liquid-liquid separation of ME indicated that active constituents responsible for the gastroprotective action are concentrated in the ethyl acetate fraction (EAF) (50\% protection) rather than in the aqueous fraction, which did not induce significant gastroprotection at the same dose $(100 \mathrm{mg} / \mathrm{kg})$. EAF induced an increase of gastric mucosa prostaglandin (PG) $\mathrm{E}_{2}$ levels, which remained high even after previous administration of indomethacin. The phytochemical profile of ME revealed that EAF contains mainly flavonoids. In conclusion, all these results suggest that ME did not show acute toxicity, but exhibited an antisecretory property, anti- $H$. pylori effect, and gastroprotective action. The observed effect did not involve the participation of nitric oxide or endogenous sulfhydryl groups. However, EAF showed a more efficient gastroprotective effect than ME at a lower dose and protected the gastric mucosa by increasing $\mathrm{PGE}_{2}$.
\end{abstract}

KEY WORDS: • Alchornea triplinervia $・$ flavonoids $・$ gastroprotective action $・$ Helicobacter pylori $\bullet$ prostaglandin $E_{2}$

\section{INTRODUCTION}

$\mathbf{P}$ EPTIC ACID ULCERS and diseases have been on the rise in today's era of globalization, which is characterized by hurry, worry, and curry. ${ }^{1}$ This disease is attributed to the imbalance between aggressive factors (including acid, pepsin, and Helicobacter pylori infection) and local mucosal defenses (like secretion of bicarbonate, mucus, and prostaglandins $[\mathrm{PGs}]) .^{2}$ The predominant causes of peptic ulcer disease in the United States are infection with $H$. pylori and use of nonsteroidal anti-inflammatory drugs (NSAIDs). H. pylori can be eradicated by triple therapy consisting of two antimicrobial agents and a proton pump inhibitor, such as lansoprazole. However, these drugs are

Manuscript received 21 November 2007. Revision accepted 31 March 2008.

Address reprint requests to: C.A. Hiruma-Lima, Departamento de Fisiologia, Instituto de Biociências, Universidade Estadual Paulista, Rubião Junior s/n, c.p. 510, CEP 18618 000, Botucatu, SP, Brazil, E-mail: hiruma@ibb.unesp.br mainly influenced by bacterial susceptibility and resistance to antimicrobial agents as well as the magnitude of acid inhibition during the treatment. Patients taking NSAIDs should discontinue their use because of peptic ulcers. ${ }^{3}$

Despite the progress through conventional chemistry and pharmacology in producing effective drugs, the plant kingdom may provide useful sources of new anti-ulcer compounds for development as pharmaceutical entities or, alternatively, as simple dietary adjuncts to existing therapies. ${ }^{4}$

The leaves and aerial parts of Alchornea triplinervia are commonly used in Brazilian folk medicine in tea form to treat gastric disturbances. ${ }^{5}$ However, there are no pharmacological or toxicological studies on this species. The only report about A. triplinervia describes the isolation of amentoflavone, isocorilagine, gallic acid, and methyl gallate from leaves. ${ }^{6}$ In contrast, other species of this genus already have been subjects of pharmacological studies: Alchornea cordifolia presented an anti-inflammatory property, whereas Alchornea castaneaefolia and Alchornea glandulosa exhibited an anti-ulcer action. ${ }^{7-9} \mathrm{Ebi}^{10}$ determined that methano- 
lic extract (ME) of A. cordifolia also showed antimicrobial activity against Pseudomonas aeruginosa, Bacillus subtilis, and Escherichia coli.

The present study was carried out to investigate the gastroprotective and anti- $H$. pylori effects of ME from $A$. triplinervia, as well as to evaluate the possible mechanism of action.

\section{MATERIALS AND METHODS}

\section{Drugs and chemicals}

The chemicals and other solutions used were all of analytical grade. All drugs and reagents were prepared immediately before use. The following drugs were used: $N$-nitroL-arginine methyl ester (L-NAME), cimetidine, $\mathrm{N}$-ethylmaleimide (NEM), indomethacin, and carbenoxolone from Sigma Chemical Co. (St. Louis, MO) and lansoprazole and piroxicam from Pfizer (São Paulo, Brazil). The extract and fractions were dissolved in saline $(0.9 \%$ $\mathrm{NaCl}$ ).

\section{Plant material and preparation of extract and fractions}

Leaves of A. triplinervia were collected at Botucatu, São Paulo State, Brazil, in August 2003, and the vegetal species was identified by Prof. Dr. Jorge Tamashiro from Campinas State University, Campinas, SP, Brazil. A voucher specimen (BOTU number 14873) was deposited at the Herbarium of the São Paulo State University campus in Botucatu, SP, Brazil. The leaves $(500 \mathrm{~g})$ of A. triplinervia were air-dried (7 days at $40^{\circ} \mathrm{C}$ ) and powdered. The powdered aerial parts were exhaustively extracted with methanol successively at room temperature (three times, 72 hours for each solvent) to produce the ME with a yield of $15 \%$ (75 g). A portion (28 $\mathrm{g}$ ) of the ME was separated into ethyl acetate/water (1:1, $\mathrm{vol} / \mathrm{vol})$, leading to $7.5 \mathrm{~g}(27 \%)$ of the ethyl acetate fraction (EAF) and $15 \mathrm{~g} \mathrm{(54 \% )}$ of the aqueous fraction (AqF). Both layers were checked by thin-layer chromatography (silica gel plates, chloroform/methanol/n-propanol/water [5:6:1:4 by volume], organic phase) and visualized with anisaldehyde sulfuric acid reagent. ${ }^{11}$ Flavonoids (yellow spots) and gallic acid derivatives (gray spots) were concentrated in the EAF, whereas tannins and free sugars remained in the aqueous layer.

\section{Analytical and quantitative measurement of total phenolic compounds by high-performance liquid chromatography-ultraviolet (UV)-photodiode array}

In the AqF and EAF, the flavonoid concentration was determined as follows. An aliquot of each fraction $(30 \mathrm{mg})$ was dissolved in $3 \mathrm{~mL}$ of water/methanol $(8: 2, \mathrm{vol} / \mathrm{vol})$, filtered in a Sep-Pak cartridge $\left(\mathrm{C}_{18}, 500 \mathrm{mg}\right.$; Sigma), and analyzed using a Varian (Walnut Creek, CA) ProStar high-performance liquid chromatography system equipped with an RP-18 column $(250 \times 4.60 \mathrm{~mm}$ i.d., $5 \mu \mathrm{m}$, Luna; Phe- nomenex, Torrance, CA) and a Rheodyne (Cotati, CA) model 7125 sample injector with a $20-\mu \mathrm{L}$ sample loop. The mobile phase was water (A) and acetonitrile (B), both with $0.05 \%$ trifluoroacetic acid, in linear gradient elution of $30-70 \%$ of B for 60 minutes at a flow rate of $1.0 \mathrm{~mL} /$ minute. The effluent was monitored using a ProStar 330 photodiode array UV detection system at $360 \mathrm{~nm}$. Compounds were identified by retention time and characteristic UV spectra and by spiking with standards and isolated compounds from a collection in our laboratory under the same conditions: ellagic acid (1), quercetin-3-O-galactopyranoside (2), quercetin-7-O-glucopyranoside (3), quercetin-3-O-glucopyranoside (4), and quercetin-3-O-arabinopyranoside (5). A stock solution $(1 \mathrm{mg} / \mathrm{mL})$ of rutin was prepared in methanol. The calibration curve was constructed utilizing seven different concentrations $(10,20,50,100,200,300$, and 500 $\mu \mathrm{g} / \mathrm{mL}$ in rutin) and analyzed in triplicate. The peak areas were correlated with the concentrations according to the calibration curve. A calibration curve using the external standard rutin was constructed to determine the total concentration of flavonoids. The calibration curve was linear over the range of $10-500 \mu \mathrm{g} / \mathrm{mL}$ with a correlation coefficient of 0.9999. All data are presented as mean \pm standard deviation of four independent experiments $(n=4)$.

\section{Animals}

Male Swiss albino mice (weighing 25-35 g) and male Wistar albino rats (weighing 150-250 g) from the São Paulo State University Central Animal House were used. The animals were fed a certified Nuvilab (Nuvital Nutrientes, Colombo, Brazil) diet with free access to tap water under standard conditions of 12 hours dark/12 hours light, humidity $(60 \pm 1.0 \%)$, and temperature $\left(21 \pm 1^{\circ} \mathrm{C}\right)$. Fasting was used prior to all assays because standard drugs were always administered orally (by gavage) or intraduodenally. Saline solution $(10 \mathrm{~mL} / \mathrm{kg})$ was always used as the vehicle. Moreover, the animals were kept in cages with raised floors of wide mesh to prevent coprophagy. All experiments were performed in the morning and followed the recommendations of the Canadian Council on Animal Care. ${ }^{12}$ The São Paulo State University Institutional Animal Care and Use Committee approved all of the protocols used.

\section{Acute toxicity}

The acute toxicity studies were performed in male and female mice $(n=10)$. A single dose of ME was administered orally to groups of animals after a 12-hour fast. Animals receiving saline served as controls. The signs and symptoms associated with ME administration (5 g/kg, p.o.) were observed at $0,30,60,120,180$, and 240 minutes after and then once a day for the next 14 days. At the end of the ME treatment period the number of survivors was recorded. The acute toxicological effect was estimated by the method described by Souza Brito. ${ }^{13}$ 


\section{Gastroprotective activity}

HCl/ethanol-induced ulcer. The experiment was performed as described by Mizui and Doteuchi. ${ }^{14}$ Mice were divided into groups of six or seven animals each that had undergone fasting 24 hours prior to receiving an oral dose of the vehicle (saline), lansoprazole $(30 \mathrm{mg} / \mathrm{kg}$ ), or ME (at a dose of 250,500 , or $1,000 \mathrm{mg} / \mathrm{kg}$ of body weight). After 50 minutes, all groups were treated orally with $0.2 \mathrm{~mL}$ of a $0.3 \mathrm{M} \mathrm{HCl} / 60 \%$ ethanol solution $(\mathrm{HCl} / \mathrm{ethanol})$ to induce gastric ulcer. Animals were sacrificed 1 hour after the administration of ethanol solution, and stomachs were excised. The extent of the lesions was measured, and the lesion index was expressed as the sum of all lesions. ${ }^{15}$

Ethanol-induced ulcer. Rats were divided into groups of five to seven animals each that had undergone fasting 24 hours prior to receiving an oral dose of the vehicle, lansoprazole $(30 \mathrm{mg} / \mathrm{kg}), \mathrm{ME}(250,500$, or $1,000 \mathrm{mg} / \mathrm{kg}), \mathrm{EAF}$ $(100 \mathrm{mg} / \mathrm{kg})$, or AqF $(100 \mathrm{mg} / \mathrm{kg})$. After 60 minutes, all groups were treated orally with $1 \mathrm{~mL}$ of absolute ethanol to induce gastric ulcer. ${ }^{16}$ Animals were sacrificed 1 hour after ethanol administration, and stomachs were excised and gastric damage was determined as described above.

NSAID gastric ulcers in mice. In this model, mice were divided into groups of seven animals each, and gastric lesions were induced with piroxicam $\left(30 \mathrm{mg} / \mathrm{kg}\right.$, s.c.). ${ }^{17} \mathrm{ME}$ $(250,500$, or $1,000 \mathrm{mg} / \mathrm{kg})$, cimetidine $(100 \mathrm{mg} / \mathrm{kg})$, or saline was administered orally 30 minutes before the induction of gastric lesion by NSAID. The animals were sacrificed 4 hours after treatment, and stomachs were removed and gastric damage was determined as described above.

Shay et al. ${ }^{18}$ ulcer production method. Mice were randomly divided into groups of seven to nine animals each that had undergone fasting for 24 hours with free access to water. Thirty minutes after oral dosing or immediately after intraduodenal administration of a single dose of ME (500 $\mathrm{mg} / \mathrm{kg})$, cimetidine $(100 \mathrm{mg} / \mathrm{kg})$ as the positive control, or vehicle (saline), pylorus ligature was performed. ${ }^{18}$ Four hours later the animals were sacrificed, the abdomen was opened, and another ligature was placed around the esophagus close to the diaphragm. The stomach was removed and inspected internally, and its contents were drained into a graduated centrifuge tube and centrifuged at $3,500 \mathrm{~g}$ for 15 minutes. The supernatant volume and $\mathrm{pH}$ were recorded with a digital pH meter (PA 200, Marconi SA, Campinas). The total acid content of gastric secretion was also determined by titration to $\mathrm{pH} 7.0$ with $0.01 \mathrm{~N} \mathrm{NaOH}$ using a digital burette (E.M., Hirschmann Technicolor, Eberstadt, Germany).

Ethanol-induced gastric lesions in L-NAME-pretreated rats. The rats were divided into six groups of seven rats each that had undergone fasting for 24 hours. The animals were treated with L-NAME $(70 \mathrm{mg} / \mathrm{kg})$ or saline intraperitoneally and 30 minutes later received an oral dose of the vehicle (10
$\mathrm{mL} / \mathrm{kg}$ ), ME (500 mg/kg), or carbenoxolone (100 mg/kg). After 60 minutes, all groups were treated orally with $1 \mathrm{~mL}$ of absolute ethanol to induce gastric ulcers. ${ }^{19}$ Animals were sacrificed 1 hour after ethanol administration, and the stomachs were excised and gastric damage was determined as described above.

Ethanol-induced gastric lesions in NEM-pretreated rats. Rats were divided into six groups of seven rats each that had undergone fasting for 24 hours. The animals had been previously treated intraperitoneally with NEM $(10 \mathrm{mg} / \mathrm{kg})$ or saline and 30 minutes later received an oral dose of the vehicle $(10 \mathrm{~mL} / \mathrm{kg}), \mathrm{ME}(500 \mathrm{mg} / \mathrm{kg})$, or carbenoxolone (100 $\mathrm{mg} / \mathrm{kg}$ ). After 60 minutes, all groups were treated orally with $1 \mathrm{~mL}$ of absolute ethanol to induce gastric ulcers. ${ }^{19}$ Animals were sacrificed 1 hour after ethanol administration, and the stomachs were excised and gastric damage was determined as described above.

$P G$ synthesis determination. Rats were divided into three groups of six animals each that, after a 24-hour fast, received one of the following solutions: saline (vehicle), EAF (100 $\mathrm{mg} / \mathrm{kg}$ ), or the combination of EAF $(100 \mathrm{mg} / \mathrm{kg})$ plus indomethacin $(20 \mathrm{mg} / \mathrm{kg}$, s.c). In this last group, EAF was administered, followed 30 minutes later by indomethacin (dissolved in 5\% sodium bicarbonate solution). Thirty minutes after treatments, all the animals were sacrificed, and the abdomen was opened. A sample of the corpus (full thickness) was excised, weighed, and suspended in $1 \mathrm{~mL}$ of $1 \mathrm{~m} M$ sodium phosphate buffer, $\mathrm{pH}$ 7.4. The tissue was finely minced with scissors and then incubated at $37^{\circ} \mathrm{C}$ for 20 minutes. $\mathrm{PGE}_{2}$ in the buffer was measured by enzyme immunoassay (Amersham Biosciences, Little Chalfont, Buckinghamshire, UK), and the absorbance was read at $450 \mathrm{~nm} .{ }^{20}$

\section{Anti-H. pylori activity}

The ME was tested to detect anti-H. pylori activity. ${ }^{21}$ The strain of H. pylori (ATCC 43504) had been isolated from patients with duodenal ulcer disease. The frozen $H$. pylori isolate was thawed and grown on 5\% sheep blood agar plates for $3-4$ days at $37^{\circ} \mathrm{C}$ in $10 \% \mathrm{CO}_{2}$ and $98 \%$ humidity. Each plate was swabbed with a sterile cotton-tipped applicator, and the cells were suspended in sterile saline to obtain turbidity equivalent to a $2.0 \mathrm{McF}$ arland standard. Mueller-Hinton broth containing $10 \%$ horse serum was added to all wells of a 96-well microtiter plate (Corning, Corning, NY). Each well was incubated with $H$. pylori at a final concentration of $1 \times 10^{5}$ colony-forming units $/ \mathrm{mL}$. The plates were incubated for 5 days in a microaerobic atmosphere at $37^{\circ} \mathrm{C}$. Following incubation, the plates were examined visually and spectrophotometrically, and the lowest concentration showing complete inhibition of growth was recorded as the minimum inhibitory concentration (MIC). Staphylococcus aureus ATCC 25923 and E. coli ATCC 25922 were used as control organisms for clarithromycin and ampicillin, respectively. The results were considered valid only when the 
MIC values for the control organisms were within the ranges established by the National Committee for Clinical Laboratory Standards (Wayne, PA).

\section{Statistical analysis}

Results were expressed as mean $\pm \mathrm{SE}$ values, and statistical significance was determined by one-way analysis of variance followed by Dunnett's or Tukey's test with $P<$ .05 defined as significant.

\section{RESULTS AND DISCUSSION}

The balance between the therapeutic versus the toxicological effects of a drug is an important parameter in assessing its applicability as an anti-ulcer or a pharmacological agent. ${ }^{22}$ As a part of this pharmacological study, ME was first investigated for acute toxicity in mice. A single oral dose of ME $(5 \mathrm{~g} / \mathrm{kg})$ did not produce any visible signs or symptoms of toxicity in the treated animals. After 14 days of administration, no animal died, and no significant macroscopic changes in daily body or organ weights were observed (data not shown). Since no acute toxicity was observed using ME, we continued our studies evaluating the effect of ME administered to rodents using different standard experimental models of induced gastric ulcer.
According to Souza Brito ${ }^{13}$ active principles from medicinal plants are generally present at low concentrations. So, in order to establish a general profile of the anti-ulcerogenic activity of the extract, we plotted the dose-response curve using three peroral doses of 250,500 , and $1,000 \mathrm{mg} / \mathrm{kg}$ to select the dose that produces the best effect.

Oral administration of absolute ethanol is noxious to the stomach by affecting the gastric mucosa topically by disrupting its barrier and provoking pronounced microvascular changes within a few minutes after its application. Konturek et $a l .^{23}$ reported that the combination of $\mathrm{HCl}$ plus ethanol also promotes stasis in gastric blood flow that contributes to the development of the hemorrhagic and necrotic aspects of tissue injury. Our results obtained with absolute ethanol and $\mathrm{HCl} /$ ethanol models gave similar results with $85-86 \%$ and $89-90 \%$ gastroprotection at the respective ME doses of 500 and $1,000 \mathrm{mg} / \mathrm{kg}$ (Table 1). These data suggest that ME displays a gastroprotective effect since it significantly reduced the occurrence of ethanol-induced ulcers.

It is commonly postulated that a mechanism that causes gastroduodenal damage involves cyclooxygenase-1 inhibition that results in gastric PG suppression. ${ }^{24}$ Deficiency of endogenous PGs is widely accepted as a major factor in the pathogenesis of gastric lesions caused by NSAIDs. ${ }^{25,26}$ However, our data showed that in the NSAID-induced gastric lesion model, the ME-treated animals exhibited an un-

Table 1. Gastroprotective Effects of ME, EAF, or AqF from A. triplinerVia on Gastric Lesions Induced by HCl/Ethanol, Piroxicam, and Absolute Ethanol in Rodents

\begin{tabular}{|c|c|c|c|c|}
\hline Model (animal) & Treatment (dose) & Number & $U L I$ & Inhibition (\%, \\
\hline \multirow[t]{5}{*}{$\mathrm{HCl} /$ ethanol (mice) $)^{\mathrm{a}}$} & Vehicle & 7 & $104.0 \pm 6.3$ & - \\
\hline & Lansoprazole & 7 & $18.0 \pm 1.9 * *$ & 83 \\
\hline & $\mathrm{ME}(250 \mathrm{mg} / \mathrm{kg})$ & 7 & $23.2 \pm 2.1 * *$ & 78 \\
\hline & $\mathrm{ME}(500 \mathrm{mg} / \mathrm{kg})$ & 6 & $14.8 \pm 1.3^{* *}$ & 86 \\
\hline & $\operatorname{ME}(1,000 \mathrm{mg} / \mathrm{kg})$ & 6 & $10.8 \pm 1.8^{* *}$ & 90 \\
\hline \multirow[t]{5}{*}{ Piroxicam (mice) ${ }^{\mathrm{b}}$} & Vehicle & 7 & $32.8 \pm 3.3$ & - \\
\hline & Cimetidine & 7 & $6.7 \pm 1.2 * *$ & 80 \\
\hline & ME $(250 \mathrm{mg} / \mathrm{kg})$ & 7 & $23.4 \pm 3.6$ & - \\
\hline & $\mathrm{ME}(500 \mathrm{mg} / \mathrm{kg})$ & 7 & $41.0 \pm 4.55$ & - \\
\hline & $\operatorname{ME}(1,000 \mathrm{mg} / \mathrm{kg})$ & 7 & $58.0 \pm 4^{*}$ & -77 \\
\hline \multicolumn{5}{|l|}{ Ethanol (rats) } \\
\hline \multirow[t]{5}{*}{ ME treatment ${ }^{\mathrm{c}}$} & Vehicle & 7 & $65.8 \pm 6.7$ & - \\
\hline & Lansoprazole & 7 & $29.0 \pm 4.2 *$ & 56 \\
\hline & $\mathrm{ME}(250 \mathrm{mg} / \mathrm{kg})$ & 7 & $47.7 \pm 16.6$ & - \\
\hline & $\mathrm{ME}(500 \mathrm{mg} / \mathrm{kg})$ & 7 & $10.1 \pm 1.3^{* *}$ & 85 \\
\hline & $\operatorname{ME}(1,000 \mathrm{mg} / \mathrm{kg})$ & 7 & $7.0 \pm 1.4^{* *}$ & 89 \\
\hline \multirow[t]{3}{*}{ EAF treatment ${ }^{d}$} & Vehicle & 5 & $100.7 \pm 11.9$ & - \\
\hline & Lansoprazole & 6 & $21.3 \pm 5.6^{* *}$ & 79 \\
\hline & EAF (100 mg/kg) & 6 & $50.5 \pm 2.5 * *$ & 50 \\
\hline \multirow[t]{3}{*}{$\mathrm{AqF}$ treatment $^{\mathrm{d}}$} & Vehicle & 6 & $92.8 \pm 16.2$ & - \\
\hline & Lansoprazole & 6 & $31.3 \pm 5.0^{* *}$ & 66 \\
\hline & $\mathrm{AqF}(100 \mathrm{mg} / \mathrm{kg})$ & 6 & $71.8 \pm 10.1$ & - \\
\hline
\end{tabular}

Data are mean \pm SE values. ULI, ulcerative lesion index.

For statistical analysis, analysis of variance followed by Dunnett's test was employed: $* P<.05, * * P<.01$.

${ }^{\mathrm{a}} F_{4 ; 29}=138.5$.

${ }^{\mathrm{b}} F_{4 ; 30}=27.2$.

${ }^{\mathrm{c}} F_{4 ; 30}=28.6$.

${ }^{\mathrm{d}} F_{5 ; 29}=47.47$. 
Table 2. EfFects of ME of A. triplinervia Administered Orally or Intraduodenally on Gastric Juice Parameters in Pylorus Ligature-Induced Gastric Lesions in Mice

\begin{tabular}{|c|c|c|c|c|c|c|c|}
\hline $\begin{array}{l}\text { Route, } \\
\text { treatment }\end{array}$ & Number & $\begin{array}{c}\text { Dose } \\
(\mathrm{mg} / \mathrm{kg})\end{array}$ & $\begin{array}{c}\text { Total acid }(\mu E q / m L / \\
4 \text { hours })\end{array}$ & $p H$ (unit) & $\begin{array}{l}\text { Gastric volume } \\
\qquad(m L)\end{array}$ & $U L I$ & $\begin{array}{l}\text { Inhibition } \\
(\%)\end{array}$ \\
\hline \multicolumn{8}{|l|}{ Intraduodenal } \\
\hline Control & 9 & - & $32.11 \pm 1.18$ & $2.50 \pm 0.34$ & $0.98 \pm 0.07$ & $49.72 \pm 4.86$ & - \\
\hline Cimetidine & 8 & 100 & $18.77 \pm 2.22 * *$ & $3.90 \pm 0.43^{*}$ & $0.82 \pm 0.06$ & $12.50 \pm 1.95^{* *}$ & 75 \\
\hline ME & 8 & 500 & $29.72 \pm 1.98$ & $1.70 \pm 0.26$ & $1.12 \pm 0.03$ & $19.80 \pm 1.63 * *$ & 60 \\
\hline \multicolumn{8}{|l|}{ Peroral } \\
\hline Control & 7 & - & $46.57 \pm 3.50$ & $3.00 \pm 0.26$ & $0.90 \pm 0.09$ & $46.57 \pm 3.52$ & - \\
\hline Cimetidine & 8 & 100 & $16.87 \pm 2.25^{* *}$ & $2.50 \pm 0.19$ & $1.09 \pm 0.08$ & $22.14 \pm 3.32 * *$ & 52 \\
\hline ME & 8 & 500 & $4.00 \pm 0.50 * *$ & $3.30 \pm 0.37$ & $1.05 \pm 0.11$ & $9.25 \pm 1.16^{* *}$ & 80 \\
\hline
\end{tabular}

Data are mean \pm SE values. ULI, ulcerative lesion index.

For statistical analysis, analysis of variance followed by Dunnett's test was employed. By the intraduodenal route: $* * P<.01$ for total acid with $F_{2 ; 22}=15.37,{ }^{*} P<.05$ for $\mathrm{pH}$ with $F_{2 ; 22}=9.99 ; P>.05$ for gastric volume with $F_{2 ; 22}=13.95$, and $* * P<.01$ for ULI with $F_{2 ; 22}=$ 39.01. By the peroral route: $* * P<.01$ for total acid with $F_{2 ; 20}=93.11,{ }^{*} P<.05$ for $\mathrm{pH}$ with $F_{2 ; 20}=2.03, P>.05$ for gastric volume with $F_{2 ; 20}=0.94$, and $* * P<.01$ for ULI $F_{2 ; 20}=47.47$.

expected result, i.e., the cytoprotection decreased as the dose was increased (Table 1). In this model, ME showed an absence of gastroprotective effect $(P>.05)$ at doses of 250 $\mathrm{mg} / \mathrm{kg}$ and $500 \mathrm{mg} / \mathrm{kg}$, while the dose of $1,000 \mathrm{mg} / \mathrm{kg}$ induced a significant increase of gastric lesions $(P<.05)$. It is highly probable that ME contains different active constituent(s), i.e., the substance or substances that protected the gastric mucosa against the damage induced by absolute ethanol and $\mathrm{HCl} / \mathrm{ethanol}$ are different from those that presented cytoprotection against the NSAID-induced gastric lesions. Among natural substances of plant origin, the literature reports that flavonoids may present this type of activity. Gracioso et $a l .{ }^{27}$ reported that increasing the dose of flavonoids changes their antioxidant activity to a pro-oxidant action, leading to an increase in gastric damage. The literature indicates that other species of the Alchornea genera present anti-inflammatory activity. ${ }^{7}$ Our results agree closely with those published by Repetto and Llesuy, ${ }^{28}$ which showed that phenolic compounds have a dual effect on PG biosynthesis, since low concentrations stimulate whereas high concentrations inhibit PGH synthase. Thus, the action mechanism possibly involves the modulation of endogenous PGs by active constituents contained in ME.

With the purpose of investigating the probable gastroprotective mechanisms involved in the action promoted by this extract, we continued our studies using only a single

Table 3. Effects of ME of A. triplinervia on Gastric Lesions Induced by Ethanol in Rats Pretreated WITH NEM OR L-NAME $(N=7)$

\begin{tabular}{llcc}
\hline $\begin{array}{l}\text { Pretreatment } \\
\text { (intraperitoneal) }\end{array}$ & $\begin{array}{c}\text { Treatment } \\
\text { (peroral) }\end{array}$ & $\begin{array}{c}\text { Dose } \\
(\mathrm{mg} / \mathrm{kg})\end{array}$ & ULI (\% inhibition) \\
\hline Saline & Vehicle & - & $73.7 \pm 6.7^{\mathrm{a}}$ \\
& Carbenoxolone & 100 & $31.8 \pm 5.9(57 \%)^{* *}$ \\
NEM $(10 \mathrm{mg} / \mathrm{kg})$ & ME & 500 & $26.6 \pm 2.8(64 \%)^{* * \mathrm{~b}}$ \\
& Vehicle & - & $148.3 \pm 15.3^{\mathrm{a}}$ \\
Saline & Carbenoxolone & 100 & $106.3 \pm 16.3(28 \%)^{*}$ \\
& ME & 500 & $40.6 \pm 4.5(73 \%)^{* * \mathrm{~b}}$ \\
L-NAME $(70 \mathrm{mg} / \mathrm{kg})$ & Vehicle & - & $135.5 \pm 18.8^{\mathrm{c}}$ \\
& Carbenoxolone & 100 & $24.0 \pm 5.0(82 \%)^{* *}$ \\
& ME & 500 & $20.1 \pm 14.9(85 \%)^{* * \mathrm{~d}}$ \\
& Vehicle & - & $197.7 \pm 15.0^{\mathrm{c}}$ \\
& Carbenoxolone & 100 & $81.7 \pm 20.4(59 \%)^{*}$ \\
& ME & 500 & $41.0 \pm 8.5(79 \%)^{* * \mathrm{~d}}$ \\
\hline
\end{tabular}

Data are mean $\pm \mathrm{SE}$ values. ULI, ulcerative lesion index.

Analysis of variance followed by Dunnett's test was used to determine significant differences from the respective control group: $* P<.05, * * P<.01$.

${ }^{a}$ Saline/vehicle versus NEM/vehicle $(P<.05)$.

${ }^{\mathrm{b} S}$ Saline/ME versus NEM/ME $(P>.05)$ by analysis of variance followed by Tukey's test.

${ }^{\mathrm{c} S}$ Saline/vehicle versus L-NAME/vehicle $(P<.05)$.

${ }^{\mathrm{d} S}$ Saline/ME versus L-NAME/ME $(P>.05)$ by analysis of variance followed by Tukey's test. 
dose of $\mathrm{ME}(500 \mathrm{mg} / \mathrm{kg})$ in subsequent assays, since this had produced the best results in the previous studies, and no significant differences were observed between groups treated with 500 or $1,000 \mathrm{mg} / \mathrm{kg}$ ME.

In pyloric ligation, the digestive effect of accumulated gastric juice (gastric hypersecretion) and the interference of gastric blood circulation are responsible for the induction of ulceration. ${ }^{29,30}$ Animals pretreated orally with ME presented a decrease of ulcerative lesions and a drop in the total acid value in gastric juice (Table 2). Otherwise, the intraduodenal administration of ME did not change any gastric juice biochemical parameter but decreased the ulcerative index. Therefore, these data indicate that ME presented antisecretory action only when this extract was given orally and that intestinal absorption of ME did not contribute to its antisecretory effect.

Ethanol-induced gastric damage is associated with a significant decrease in the mucosal sulfhydryl ( $\mathrm{SH}$ ) level, including reduced gluthathione, and pretreatment with $\mathrm{SH}$ blockers prevents gastroprotection of SH-containing compounds. ${ }^{31,32}$ Our data show that pretreatment with the $\mathrm{SH}$ blocker NEM did not reduce the mucosal protection observed with ME treatment. These findings suggest that an increase of endogenous SH is not involved in the gastroprotective effect of ME, as shown in Table 3.

Vascular changes in gastric mucosa appear to be the most pronounced feature of absolute ethanol-induced injury. ${ }^{33}$ Maintenance of mucosal vasculature and normal blood flow may constitute the major cytoprotective mechanism. ${ }^{34}$ As shown in Table 3, L-NAME, a nitric oxide synthase inhibitor, also did not attenuate the gastroprotection observed

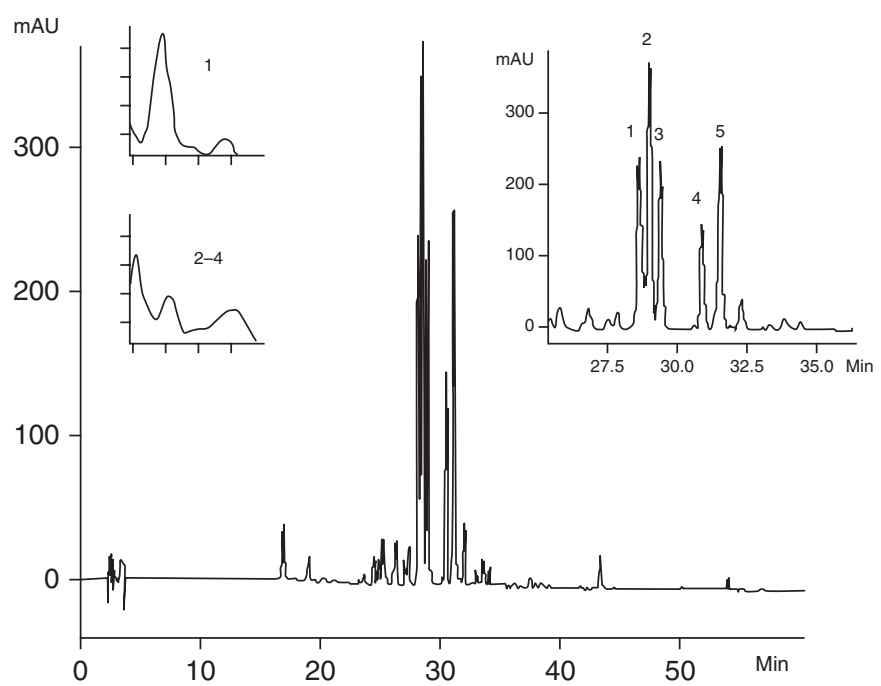

FIG. 1. High-performance liquid chromatography profile of EAF from A. triplinervia. Chromatographic conditions were as follows: RP18 column, $250 \times 4.6 \mathrm{~mm}$ (i.d.), $5 \mu \mathrm{m}$; elution with water $(0.05 \%$ trifluoroacetic acid)/acetonitrile ( $0.05 \%$ trifluoroacetic acid), $30 \%$ to $70 \%$ in 60 minutes; flow rate, $1.0 \mathrm{~mL} /$ minute; $\lambda=360 \mathrm{~nm}$. mAU, milli-absorbance units.

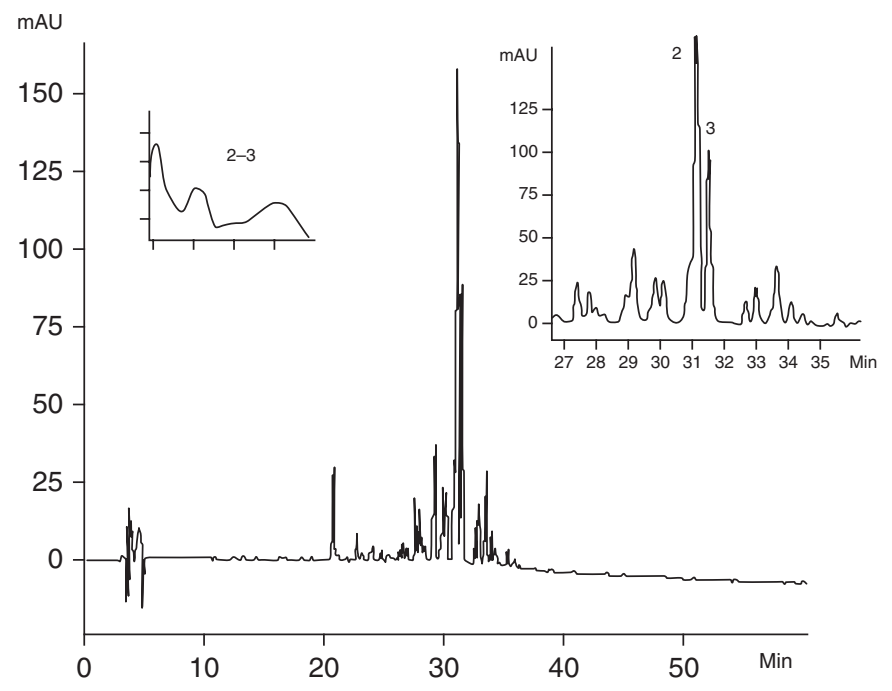

FIG. 2. High-performance liquid chromatography profile of $\mathrm{AqF}$ from A. triplinervia. Chromatographic conditions were as follows: RP18 column, $250 \times 4.6 \mathrm{~mm}$ (i.d.), $5 \mu \mathrm{m}$; elution with water $(0.05 \%$ trifluoroacetic acid)/acetonitrile ( $0.05 \%$ trifluoroacetic acid), $30 \%$ to $70 \%$ in 60 minutes; flow rate, $1.0 \mathrm{~mL} /$ minute; $\lambda=360 \mathrm{~nm}$. mAU, milli-absorbance units.

for ME, suggesting that endogenous nitric oxide did not participate in the protective effect of ME.

We also evaluated the anti- $H$. pylori activity of ME. In the course of the study, A. triplinervia ME was found to present antibacterial activity against the standard strain of $H$. pylori (ATCC 43504). The results showed that the MIC of ME against $H$. pylori was $0.25 \mathrm{mg} / \mathrm{mL}$. The literature reported that an MIC of $<0.50 \mathrm{mg} / \mathrm{mL}$ is considered interesting for extracts. ${ }^{21,35} \mathrm{We}$ conclude that ME presents excellent antimicrobial action against one of the most important factors that cause gastric ulceration.

In order to better comprehend the effect of ME on gastric injuries, we separated ME into ethyl acetate and water, thus obtaining two fractions (EAF and AqF). The pretreatments with these fractions were also evaluated against the ethanol-induced gastric lesions that had resulted in the best results with ME. We observed that the active constituents responsible for the protective action are concentrated in the EAF (50\% protection), rather than in the $\mathrm{AqF}$, which did not induce significant gastric protection at the same dose (Table 1). Therefore, we can conclude that the active constituents responsible for the protective action are concentrated in the EAF and not in the AqF.

We also determined spectrophotometrically the total concentration of flavonoids in the A. triplinervia leaves. The flavonoid contents were $19.73 \%(197.3 \pm 0.19 \mathrm{mg} / \mathrm{g})$ in the EAF and $1.3 \%(13.1 \pm 0.04 \mathrm{mg} / \mathrm{g})$ in the AqF from ME. In agreement with these results, Figures 1 and 2 present the chromatograms and UV spectra of the respective fractions $\mathrm{EAF}$ and $\mathrm{AqF}$ from ME. The EAF contained primarily five phenolic compounds: ellagic acid, quercetin-3-O-galactopyranoside, quercetin-7-O-glucopyranoside, quercetin-3-O- 


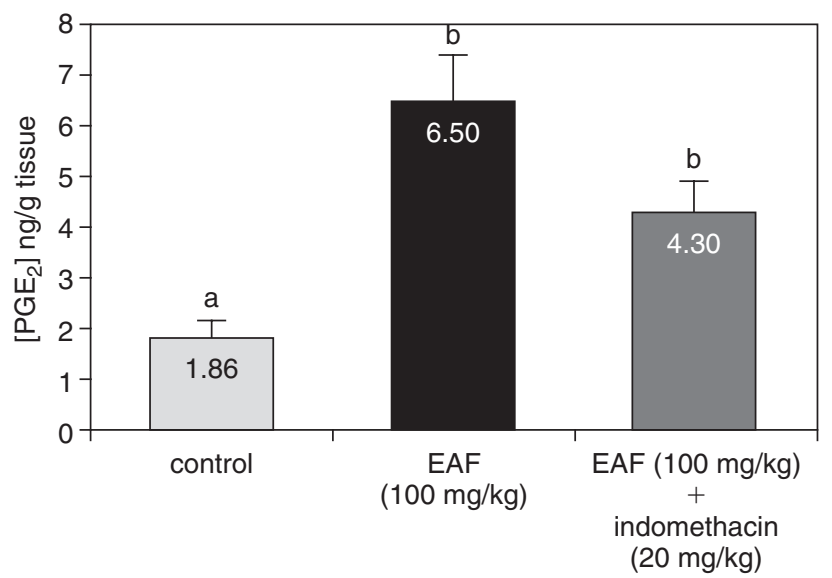

FIG. 3. Effect of EAF from A. triplinervia on $\mathrm{PGE}_{2}$ levels in gastric mucose from rats. Data are mean $\pm \mathrm{SE}$ values. For statistics, analysis of variance followed by Tukey's test was used. ${ }^{a, b}$ Different letters represent significant differences between groups.

glucopyranoside, and quercetin-3-O-arabinopyranoside. The $\mathrm{AqF}$, which did not exhibit gastroprotective action, contained only quercetin-3-O-galactopyranoside and quercetin7-O-glucopyranoside. So these quantitative (almost 15 times more flavonoid content than found in EAF) and qualitative differences between fractions were essential to the cytoprotective effect observed with ME.

Although PGs play an important role in modulating gastric mucosal integrity and in regulating gastric acid secretion, little is known regarding regulation of PG synthesis by the stomach. ${ }^{20}$ Arakawa et al..$^{36}$ suggested that PGs accelerate ulcer healing, possibly via angiogenesis, epithelial cell proliferation, reconstruction of extracellular matrices, suppression of inflammatory cell infiltration, and production of growth factors such as hepatocyte growth factor and transforming growth factor- $\beta$. In the present work, we observed that treatment with EAF induced a significant jump in $\mathrm{PGE}_{2}$ production to double the basal levels. These results explain the gastroprotective action obtained from ME against ethanol as well as the antisecretory action observed under the pylorus ligature method. It is notable that our previous work with $A$. castaneaefolia extract also produced an increase in $\mathrm{PGE}_{2}$ production. ${ }^{8}$ However, more interesting results were obtained in the group of animals treated with EAF and pretreated with indomethacin (an inhibitor of cyclooxygenase enzyme). Results displayed in Figure 3 show that EAF was able to maintain a high $\mathrm{PGE}_{2}$ level despite administration of indomethacin. These results may alter the therapy of gastroprotective drugs associated with NSAIDs because EAF was able to promote a sustained increase of $\mathrm{PGE}_{2}$ levels, which is vital to the integrity of gastric mucosa. Furthermore, the association of EAF and NSAID was not capable of reducing levels of $\mathrm{PGE}_{2}$ release in a significant manner. Park et al. ${ }^{37}$ also evaluated flavonoids originating from Scutellaria baicalensis and observed that this compound provides a cytoprotective effect; they inferred dual action of wogonin on arachidonic acid metabolism, including the induction of cyclooxygenase- 2 expression.

In conclusion, all these results taken together suggest that $\mathrm{ME}$ from the leaves of $A$. triplinervia did not show acute toxicity and exhibited an antisecretory property, anti-H. pylori effect, and gastroprotective action. The gastroprotective effect presented by the EAF was proven more efficient than that shown by the ME, while the gastroprotective action occurred by increasing the $\mathrm{PGE}_{2}$ level.

\section{ACKNOWLEDGMENTS}

We are grateful to the Fundação de Amparo à Pesquisa do Estado de São Paulo (FAPESP), Capes, and CNPq for grants to Z.P.L., W.V., A.R.M.S.B., and C.A.H.-L. and to the Biota-FAPESP Program for funding.

\section{AUTHOR DISCLOSURE STATEMENT}

No competing financial interests exist.

\section{REFERENCES}

1. Jain KS, Shah AK, Bariwal J, Shelke SM, Kale AM, Jagtap JR, Bhosale AV: Recent advances in proton pump inhibitors and management of acid-peptic disorders. Bioorg Med Chem 2007;15: 1181-1205.

2. Chan FKL, Leung WK: Peptic-ulcer disease. Lancet 2002;360: 933-941.

3. Ramakrishnan K, Salinas RC: Peptic ulcer disease. Am Fam Physician 2007;76:1005-1012.

4. Schmeda-Hirschmann G, Yesilada E: Traditional medicine and gastroprotective crude drugs. J Ethnopharmacol 2005;100:61-66.

5. Silva EM, Hiruma-Lima CA, Lólis SF: Etnobotânica no município de Porto Nacional [abstract]. In: Symposium of Brazilian Medicinal Plants. Universidade Federale de Mato Grosso, Cuiabá, Brazil, 2000, p. 106.

6. Braca A, Mendez J, Menichini F, Morelli I: Constituents of Alchornea triplinervia (Euphorbiaceae). Biochem Syst Ecol 2002;30:1109-1111.

7. Manga MH, Brkic D, Marie DEP, Quetin-Leclerc Q: In vivo antiinflammatory activity of Alchornea cordifolia (Schumach \& Thonn.) Müll. Arg. (Euphorbiaceae). J Ethnopharmacol 2004;92:209-214.

8. Hiruma-Lima CA, Calvo TR, Rodrigues CM, Andrade FD, Vilegas W, Brito AR: Antiulcerogenic activity of Alchornea castaneaefolia: effects on somatostatin, gastrin and prostaglandin. $\underline{J}$ Ethnopharmacol 2006;104:215-224.

9. Calvo TR, Lima ZP, Silva JS, Ballesteros KV, Pellizzon CH, Hiruma-Lima CA, Tamashiro J, Brito ARMS, Takahira RK, Vilegas W: Constituents and antiulcer effect of Alchornea glandulosa: activation of cell proliferation in gastric mucosa during the healing process. Biol Pharm Bull 2007;30:451-459.

10. Ebi GC: Antimicrobial activities of Alchornea cordifolia. Fitoterapia 2001;72:69-72.

11. Wagner H, Bladt H, Zgainski EM: Plant Drug Analysis. Springer, Berlin, 1984.

12. Olfert ED, Cross BM, McWilliam AA: Guide to the Care and Use of Experimental Animals. Canadian Council on Animal Care, Ottawa, 1993. 
13. Souza-Brito ARM: Manual de Ensaios Toxicológicos In Vivo. Editora da Unicamp, Campinas, Brazil, 1995, pp. 15-22.

14. Mizui T, Douteuchi M: Effect of polyamines on acidified ethanolinduced gastric lesions in rats. Jpn J Pharmacol 1983;33:934-945.

15. Szelenyi I, Thiemer K: Distention ulcer as a model for testing of drugs for ulcerogenic side effects. Arch Toxicol 1978;41:99-105.

16. Morimoto Y, Shimohara K, Oshima S, Sukamoto T: Effects of the new anti-ulcer agent KB-5492 on experimental gastric mucosal lesions and gastric mucosal. Jpn J Pharmacol 1991;57:595-605.

17. Puscas I, Puscas C, Coltau M, Pasça R, Torres J, Márquez M, Herrero E, Fillat O, Ortiz J: Comparative study of the safety and efficacy of ebrotidine versus ranitidine and placebo in the prevention of piroxicam-induced gastroduodenal lesions. Arzneimittelforschung 1997;47:568-572.

18. Shay H, Komarov SA, Fels SS, Meranze D, Gruenstein M, Siplet $\mathrm{H}$ : A simple method for the uniform production of gastric ulceration in the rat. Gastroenterology 1945;5:43-61.

19. Arrieta J, Benitez J, Flores E, Castillo C, Navarrete A: Purification of gastroprotective triterpenoids from the stem bark of Amphipterygium adstringens; role of prostaglandins, sulfhydryls, nitric oxide and capsaicin-sensitive neurons. Planta Med 2003;69:905-909.

20. Curtis GH, MacNaughton WK, Gall DG, Wallace JL: Intraluminal pH modulates gastric prostaglandin synthesis. Can J Physiol Pharmacol 1995;73:130-134.

21. Hacem CY, Clarridge JE, Reddy R, Flamm R, Evans DG, Tanaka SK, Graham DY: Antimicrobial susceptibility testing of Helicobacter pylori. Diagn Microbiol Infect Dis 1996;41:24-37.

22. Ekwall B, Ekwall K: Comments on the use of diverse cell systems in toxicity testing. Altern Lab Anim 1988;15:193-200.

23. Konturek PC, Brzowski T, Sliwoswski Z: Involvement of nitric oxide and prostaglandin in gastroprotection induced by bacterial lipopolysaccharide. Scand J Gastroenterol 1988;33:691-700.

24. Peng S, Duggan A: Gastrointestinal adverse effects of nonsteroidal anti-inflammatory drugs. Expert Opin Drug Safety 2005;4:157-169.

25. Wolfe MM, Lynda S, Sachs G: Proton pump inhibitors and gastric acid secretion. Am J Gastroenterol 2001;96:3467-3468.
26. Peskar BM, Maricic N: Role of prostaglandins in gastroprotection. Dig Dis Sci 1998;43(Suppl):23S-29S.

27. Gracioso JS, Vilegas W, Hiruma-Lima CA, Souza-Brito ARM: Effects of tea from Turnera ulmifolia L. on mouse gastric mucosa support the Turneraceae as a new source of antiulcerogenic drugs. Biol Pharm Bull 2002;25:470-491.

28. Repetto MG, Llesuy SF: Antioxidant properties of natural compounds used in popular medicine for gastric ulcers. $\underline{\mathrm{Braz} J \mathrm{Med}}$ Biol Res 2002;35:523-534.

29. Brodie BB, Costa E, Dlabac A, Neff NH, Smookler HH: Application of steady state kinetics to the estimation of synthesis rate and turnover time of tissue catecholamines. J Pharmacol Exp Ther 1966;154:493-498.

30. Rastogi L, Patnaik GK, Dikshit M: Free radicals and antioxidant status following pylorus ligation induced gastric mucosal injury in rats. Pharmacol Res 1998;38:125-132.

31. Szabo S, Trier JS, Frankel PW: Sulfhydryl compounds may mediate gastric cytoprotection. Science 1981;214:200-202.

32. Lopez A, Motilva V, Alarcón de la Lastra C, Martin MJ, La Casa $\mathrm{C}$ : The role of gastric mucosal sulphydryls in the ulcer-protecting effects of cisapride. J Pharm Pharmacol 1996;48:37-40.

33. Laine L, Weinstein WM: Histology of alcoholic hemorrhagic "gastritis," a prospective evaluation. Gastroenterology 1988;94: 1254-1262.

34. Szallasi A, Biro T, Modarres S, Garlaschelli L, Petersen M, Klusch A, Vidari G, Jonassohn M, De Rosa S, Sterner O, Blumberg PM, Krause JE: Dialdehyde sesquiterpenes and other terpenoids as vanilloids. Eur J Pharmacol 1998;356:81-89.

35. Gadhi CA, Benharref A, Jana M, Lozniewski A: Anti-Helicobacter pylorus activity of Aristolochia paucinervis pomel extracts. J Ethnopharmacol 2001;75:203-205.

36. Arakawa T, Higuchi K, Fukuda T, Fujiwara Y, Kobayashi K, Kuroki T: Prostaglandins in the stomach: an update. $\underline{J \text { Clin Gas- }}$ troenterol 1998;27(Suppl):S1-S11.

37. Park S, Hahm K, Oh T, Jin J, Choue R: Preventive effect of the flavonoid, wogonin, against ethanol-induced gastric mucosa damage in rats. Dig Dis Sci 2004;49:384-394. 


\section{This article has been cited by:}

1. Jorge M.B. Vítor, Filipa F. Vale. 2011. Alternative therapies for Helicobacter pylori: probiotics and phytomedicine. FEMS Immunology \& Medical Microbiology n/a-n/a. [CrossRef]

2. Ariane Leite Rozza, Thiago de Mello Moraes, Hélio Kushima, Alexandre Tanimoto, Márcia Ortiz Mayo Marques, Taís Maria Bauab, Clélia Akiko Hiruma-Lima, Cláudia Helena Pellizzon. 2011. Gastroprotective mechanisms of Citrus lemon (Rutaceae) essential oil and its majority compounds limonene and $\beta$-pinene: Involvement of heat-shock protein-70, vasoactive intestinal peptide, glutathione, sulfhydryl compounds, nitric oxide and prostaglandin E2. Chemico-Biological Interactions 189:1-2, 82-89. [CrossRef]

3. A. Quílez, B. Berenguer, G. Gilardoni, C. Souccar, S. de Mendonça, L.F.S. Oliveira, M.J. Martín-Calero, G. Vidari. 2010. Antisecretory, anti-inflammatory and anti-Helicobacter pylori activities of several fractions isolated from Piper carpunya Ruiz \& Pav. Journal of Ethnopharmacology 128:3, 583-589. [CrossRef] 